\title{
En bUSCA DEl apoyo de América. El EXILIO ESPAÑol ante la Conferencia de Cancilleres De Chapultepec (Febrero-Marzo de 1945)
}

\author{
In search of the support from America. The Spanish Exile at \\ The Conference of Chancellors of Chapultepec (february-march 1945)
}

\author{
Carlos Sola Ayape*
}

\section{RESUMEN}

A comienzos de 1945, todavía en el marco de la Segunda Guerra Mundial y a poco de cumplirse los seis años desde el final de la Guerra Civil, el exilio español aprovechó la celebración en la ciudad de México de la Conferencia de Cancilleres de Chapultepec para reclamar el apoyo solidario de América con vistas a acabar con la dictadura franquista. Así, en este contexto de panamericanismo y de inminente posguerra, en el presente artículo se presentan y analizan las diferentes propuestas que remitieron los refugiados españoles en su anhelo de asegurar un pronto regreso a la España perdida.

Palabras clave: Conferencia de Chapultepec, Conferencia de San Francisco, exilio español, franluismo, Manuel Ávila Camacho, panamericanismo, Segunda Guerra Mundial.

\section{Abstract}

At the beginning of 1945, still in the frame of the Second World War and to little of be fulfilling six years from the end of the Civil War, the Spanish exile took advantage of the celebration in Mexico City of the Foreign Ministers' Conference of Chapultepec, to claim the solidary support of America with a view to finishing with the pro-Franco dictatorship. This way, and in this context of Pan Americanism and of imminent postwar period, in the present article they appear and analyze the different offers that the Spanish refugees sent in his longing to assure a prompt return to the lost Spain.

Keywords: Chapultepec's Conference, Conference of San Francisco, Spanish exile, Franco's regime, Manuel Ávila Camacho, Pan Americanism, The Second World War.

Recepción: 16 de octubre de 2015.

Dictamen 1: 17 de diciembre de 2015.

Dictamen 2: 21 de diciembre de 2015.

* Instituto Tecnológico y de Estudios Superiores de Monterrey, campus Ciudad de México. Correo electrónico: csola@itesm.mx 
Cuanto más pronto se produzca el hecho de la ruptura de relaciones diplomáticas con Franco, tanto más fácil será la tarea que resta por hacer, para afianzar la victoria y la paz que el mundo necesita.

Salvador Etcheverría Brañas, 28 de Febrero de 1945.

\section{DE LOS PROBLEMAS DE LA GUERRA Y DE LA PAZ:}

\section{A MODO DE INTROITO}

En las postrimerías de la Segunda Guerra Mundial, y tan sólo unos días después de la celebración de la Conferencia de Yalta ( 4 al 11 de febrero de 1945), donde los tres grandes - Inglaterra, los Estados Unidos y la Unión Soviética- dieron su respaldo a la creación de la Organización de las Naciones Unidas para la gestión del nuevo tiempo de posguerra, tuvo lugar en la ciudad de México la llamada Conferencia Interamericana sobre Problemas de la Guerra y de la Paz, más conocida como la Conferencia de Cancilleres de Chapultepec. ${ }^{1}$

Desde el 21 de febrero hasta el 8 de marzo de 1945, en un contexto internacional todavía marcado por la guerra contra el totalitarismo nazi-fascista, ${ }^{2}$ los responsables de la política exterior de 20 países de América - con la presencia de la gran potencia del norte y con las ausencias de Canadá y Argentina $-{ }^{3}$ se reunieron en el castillo de Chapultepec, por invitación expresa del presidente mexicano Manuel Ávila Camacho, para madurar una posición conjunta ante los grandes retos que se avecinaban en torno a la construcción de la paz tras la terminación de la guerra. De ellos, uno de los más importantes era el acuerdo conjunto ante la inminente Conferencia Internacional de San Francisco, pensada para fines de abril de ese año y donde se esperaba la concurrencia de un total de 50 países. ${ }^{4}$

\footnotetext{
1 Archivo Histórico Genaro Estrada (en adelante, AHGE), expediente L-E-469.

2 Durante el desarrollo de la cumbre, la prensa mexicana informó puntualmente del progresivo cerco que las tropas a liadas venían imponiendo sobre Berlín, en lo que acabaría siendo el prefacio de la rendición de Hitler y la posterior capitulación de la Alemania del Tercer Reich (véase, por ejemplo, El Nacional, 1945, 20 de febrero, p. 1, y Excélsior, 1945, 27 de febrero, p. 3).

3 Si en ese entonces Canadá era un país vinculado a Inglaterra, en el caso de Argentina, su gobierno militar de Edelmiro Farrely Juan Domingo Perón acabó aceptando la invitación de adherirse a los principios y declaraciones recogidos en el acta final de la cumbre (AHGE, expediente L-E-469).

4 Para Rafael Velázquez, la cumbre de Chapultepec estuvo marcada por los futuros problemas económicos y políticos de la posguerray por la necesidad de madurar un criterio común de cara a la nueva organización internacional que se estaba gestando (Velázquez Flores, 2007, pp. 125-127).
} 
De entrada, dando cauce al espíritu panamericano de otras cumbres como la de La Habana (1940) o Río de Janeiro (1942), los cancilleres americanos se propusieron, en la capital mexicana, encauzar la retórica de la buena vecindad, no sólo hacia el fortalecimiento de una alianza militar en caso de agresión externa, según el principio rector de "agredir a uno es atacar a todos", sino también hacia el fortalecimiento de una solidaridad socioeconómica al interior del continente desde el respeto a la soberanía nacional de todos y cada uno de los países que habían participado en el conflicto del lado aliado (Excélsior, 1945, 4 de marzo, p. 4). "Si el orden internacional de mañana se estableciese exclusivamente tomando en cuenta la opinión de los poderosos — advirtió el presidente mexicano en su discurso inaugural-, toda esta guerra resultaría a la postre una enorme y grotesca ficción".5

En este contexto de retos y problemas americanos, un actor se coló por debajo de los sólidos muros del citadino castillo de Chapultepec — el exilio español一, producto de aquella España partida en dos por la Guerra Civil y el posterior triunfo del bando nacional capitaneado por el general Francisco Franco. En busca del apoyo de América, los refugiados españoles se hicieron presentes antes, durante y después del desarrollo de la Conferencia Interamericana, con el fin de afianzar el progresivo desmoronamiento de la dictadura franquista y el pretendido regreso a la España perdida. Si bien, al inicio de la cumbre, la Comisión de Iniciativas, presidida por el canciller mexicano Ezequiel Padilla, no tuvo a bien incluir la problemática española en la agenda de trabajo de los cancilleres americanos por considerar que no era un asunto estrictamente americano, ${ }^{6}$ durante aquellos días se pudo comprobar la verdadera naturaleza de la tragedia de un pueblo errante en el exilio, que se presentaba ante las democracias americanas como la primera víctima del nazi-fascismo y que, por si esto fuera poco, su destino seguía estando condicionado por un franquismo que potencialmente también podía ser una seria amenaza para las naciones de América. ${ }^{7}$

En estas circunstancias, haciendo un ejercicio de contextualización histórica, es importante significar que para ese entonces la España peregrina estaba a unos

5 Véase el discurso inaugural de la Conferencia de Cancilleres de Chapultepec en El Nacional, 1945, 22 de febrero, p. 1. ${ }^{6}$ En la reunión del Comité Ejecutivo, el canciller Ezequiel Padilla llegó a solicitar a los cancilleres de América la ruptura de relaciones con la España franquista (Portero, 1989, p. 77). Semanas después, en el marco de la Conferencia de San Francisco, el presidente Ávila Camacho cuestionó el continentalismo exhibido en la cumbre de Chapultepec, en el entendido de que "la paz es indivisible y esta verdad se compagina muy mal con la idea de convertir los conflictos de América en hechos no susceptibles de ser analizados por Europa” (República Española, 1945,15 de abril, p. 15).

7 Sobre las razones de la negativa de los cancilleres americanos de abordar la problemática del exilio español en la cumbre de Chapultepec, véase Sola Ayape, 2015a, pp. 77-88. 
meses de cumplir su sexto año de exilio, inaugurado — simbólicamente- desde que aquel primero de abril de 1939 el general Franco declaró oficialmente el fin de la Guerra Civil. ${ }^{8}$ A partir de ese momento, la consecuencia no podía ser más inmediata, bajo el supuesto categórico de que la victoria del bando nacional franquista habría de suponer la consecuente derrota del bando republicano. El vencedor acabó imponiendo la victoria sobre el perdedor. Para los que no pudieron o supieron salir, les esperaba una dura e implacable represión física; para los que acertaron a abandonar su patria de origen, un largo, incierto y desconcertante exilio. A partir de aquel abril de 1939, la diáspora republicana se disponía a forjar la geografía de uno de los exilios más significativos de la historia contemporánea. La Unión Soviética, Estados Unidos o determinados países latinoamericanos como el México del general Lázaro Cárdenas fueron algunos de los enclaves de destino y refugio.

Y todo así, en tanto que en España el bando vencedor, de la mano del general Franco, fue forjando un régimen unipersonal de carácter manu militari desde la satisfacción de haber salido victorioso de su guerra contra el "maligno" comunista, pero ante la necesidad perentoria de ondear el estandarte de la cruz para seguir haciendo una cruzada contra los enemigos de la España inmortal, entre otros, el socialismo, el comunismo, el laicismo o la masonería. Desde ese entonces, se pudo comprobar que el nuevo régimen, que habría de suceder a aquella Segunda República nacida en aquel 14 de abril de 1931, habría de quedar inexorablemente vinculado a la biografía de su mentor, ese militar que desde muy pronto se presentaría ante los de adentro y los de afuera como el "Caudillo de España por la Gracia de Dios”. A la postre, el tiempo acabaría demostrando que aquella España partida en dos no vería el comienzo de su unificación hasta la muerte del dictador en noviembre de 1975.

Allende las fronteras, también es importante advertir que el devenir de estas dos Españas quedó condicionado de forma categórica por los vaivenes de la incierta y compleja realidad internacional del momento. ${ }^{9}$ Si la Guerra Civil española terminaba en abril de 1939, en septiembre de ese mismo año Adolf Hitler, el mismo que ofreció su ayuda militar al bando franquista, daba por inaugurada su política imperialista con la ocupación de un país soberano como Polonia. El nazismo cumplía

8 Sobre los diferentes pormenores del exilio español, véase Alted, 2005; Cabeza, 1997; López, 2013, y Sánchez, 2011.

9 La Guerra Civil marcó de una u otra forma la agenda internacional no sólo en un foro como la ginebrina Sociedad delas Naciones, sino también en la política interna de diferentes estados como Francia o Inglaterra, por no hablar de la Italia de Mussolini y de la Alemania de Hitler (véase Moradiellos, 2001, y Sánchez y Herrera, 2011). 
con la promesa de recuperar su "espacio vital" y, por consiguiente, el sometimiento de Europa no era sino el primer paso para lograr unas ambiciones expansionistas de mayor alcance. Si bien la Segunda Guerra Mundial había comenzado años atrás en España, el proceso de ocupación europea por parte de Alemania se mostraba como el signo inequívoco de que el mundo había entrado definitivamente en guerra. La internacionalización del conflicto era un hecho, más aún cuando el 8 de diciembre de 1941 el presidente norteamericano Franklin Delano Roosevelt declaraba la guerra contra Japón tras el ataque nipón a la base estadounidense de Pearl Harbor.

En el caso que nos ocupa, como era de prever, la suerte del exilio español durante sus primeros años estuvo condicionada, primero, por la supervivencia del régimen franquista en aquellos años de conflicto bélico internacional, segundo, por los procesos de integración en los respectivos países de acogida y, finalmente, por el devenir de una guerra que muy pronto se identificó como una batalla dialéctica abierta entre las democracias y los totalitarismos fascistas. El triunfo de las primeras — encabezadas, a la postre, por Estados Unidos- sobre las potencias del Eje - Alemania, Italia y Japón - permitió al republicanismo español en el exilio abrigar la esperanza de un cambio prometedor en su destino. La derrota del totalitarismo abrigó la ilusión de una consecuente y hasta inminente caída del régimen franquista y, por consiguiente, un regreso a la patria perdida. En suma, si el triunfo de la democracia sobre el fascismo habría de conllevar, entre otros, la restauración de los regímenes democráticos anteriores a la guerra, sobre el papel el republicano español no habría de ser una excepción.

Por eso, y bajo la advertencia de una pronta posguerra, no fueron casuales los diferentes movimientos que se produjeron en el seno de la familia política republicana, en especial desde los primeros días de aquel decisivo 1945. De hecho, la sola comunicación entre los líderes republicanos en el exilio advertía de la presencia de un nuevo tiempo. A modo de ejemplo, hay que recordar el telegrama que en enero de 1945 el líder republicano Juan Negrín — presidente del gobierno español republicano hasta el golpe de Estado del general Casado en marzo de 1939, esto es, unos días antes del fin de la Guerra Civil— había remitido a Diego Martínez Barrio, entonces presidente de la Diputación Permanente, en el que lo hacía partícipe de la "necesidad absoluta de coaligar en un programa común de acción las fuerzas leales al régimen constitucional y de revivir sus instituciones”, aunque hacía un especial énfasis en "la discusión, la negociación y la unanimidad como premisas para evitar que el proyecto se malograse por determinaciones precipitadas" (Azcárate, 2010, p. 305). No obstante, la decisión unilateral de 
Martínez Barrio de reunir a las cortes republicanas en el Club France de la ciudad de México — al final, fallidas ante la falta de quórum — no hizo sino advertir las fisuras internas y la falta de entendimiento que se venían dando en el interior de la familia del exilio español.

Segundando una lógica dialéctica, la reacción del negrinismo no se haría esperar. Un periódico como República Española, partidario de las aspiraciones negrinistas, hacía su particular balance del fracaso de aquella convocatoria a cortes: "Dada la imposibilidad de que Martínez Barrio reúna quorum parlamentario en México, la posición de Negrín ha quedado reforzada, y hoy es el único hombre de Estado español que puede intentar una transición entre el régimen franquista y la democracia republicana" (República Española, 1945, 15 de febrero, p. 1). En esta línea, el 29 de enero los negrinistas se dieron cita en un gran mitin en la Arena México de la capital mexicana, contando con la presencia de exiliados como Vicente Uribe o Ramón Lamoneda, entre otros. Si bien, de manera unánime, los distintos oradores apelaron al espíritu de unidad para afrontar con esperanzas de éxito aquella coyuntura internacional de posguerra, algunos personajes como Álvarez del Vayo no tuvieron reparo en señalar la urgencia de que Juan Negrín, cuya inminente llegada a México sería anunciada en el foro, retomara definitivamente el timón político del exilio. El mensaje era claro: si Martínez Barrio no había sido capaz de lograr consensos para abrir las puertas de las cortes, sólo un líder político como Negrín reunía las credenciales para hacerlo. En palabras de Antonio Velao, quien fuera ministro de Obras Públicas en varios periodos de la Segunda República, "ha tomado cuerpo la solución de reconocimiento de la legitimidad del gobierno Negrín [...] como una solución para aunar nuestros esfuerzos" (República Española, 1945, 15 de abril, p. 3).

De hecho, la notoriedad de las fracturas políticas en el exilio español, ${ }^{10}$ con la consiguiente crisis de liderazgo, llevó a que en la Arena México se escuchase la voz del presidente Ávila Camacho, a través de Fernando Casas Alemán, su subsecretario de Gobernación. ${ }^{11}$ El mensaje institucional del gran país de acogida no podía ser más elocuente: "En estos momentos trascendentales me da la confianza de exhortaros a unir vuestros arrestos, a considerar que la hora más fecunda de la vida no es la que nos lleva la satisfacción de un anhelo personalista, sino la que se

10 Sobre el enfrentamiento entre líderes políticos del exilio como Indalecio Prieto y Juan Negrín, véase, entre otros, Cabezas, 2005, pp. 421-456, y Velázquez, 2014.

11 Sobre la particular relación entre México y el exilio español, véase, entre otros, Mateos, 2009; Mateos, 2005; Serra, 2011, y Hoyos, 2012. 
entrega a la realización de una obra conjunta, noble y buena que alcance los más amplios horizontes" (Matesanz, 1978, pp. 112 y 113).

$\mathrm{Si}$, para la causa del exilio, el año de 1945 había comenzado con un intento fallido de reunión de cortes, unos meses más tarde, el 17 de agosto, poco menos de un centenar de diputados españoles, presentes todos ellos en la última sesión parlamentaria antes de abandonar España, se reunieron en el salón del cabildo de la capital mexicana para proceder a la reconstrucción definitiva de las instituciones republicanas. Previamente, el presidente Ávila Camacho les había concedido las prerrogativas necesarias para que por espacio de unas horas aquel simbólico local en el zócalo capitalino se convirtiera en territorio español y así poder reunirse las cortes. ${ }^{12}$ De dicha reunión salió nombrado Diego Martínez Barrio como nuevo presidente de la República Española, quien después nominaría a José Giral como presidente del nuevo gobierno republicano en el exilio (Sola Ayape, 2013, p. 68). Las advertencias de Juan Negrín en los días previos, con motivo de su discurso pronunciado en el palacio de Bellas Artes de la ciudad de México, no eran gratuitas: "No hay tiempo que perder. Se necesita la colaboración de todos. Es tarde; cada minuto que pasa está siendo demasiado tarde. El gobierno no pone condiciones. Que se haga lo que se quiera, que se haga lo que se haga, con tal de que sea constitucionalmente y de que el gobierno que salga mañana pueda decir que habla en nombre de la República". ${ }^{13}$

Unos meses después, desde Londres, Manuel de Irujo, en su condición de ministro de Industria y Comercio del gobierno republicano español en el exilio español, pronunció estas elocuentes palabras de reconocimiento y gratitud: "Gracias al gobierno mejicano han podido reconstituirse las instituciones centrales republicanas, la Presidencia de la República, el Parlamento, el Gobierno y el Tribunal Supremo. Bajo el sol eterno de Méjico, al calor de su suelo ubérrimo, rodeados de un ambiente en el que nunca nos sentimos extranjeros, ha renacido con fuerza y vigor de unidad y de victoria la vida de la democracia republicana. Cualquiera que sea la suerte que hayamos de correr, no olvidaremos jamás el apoyo resuelto,

12 Juan Negrín se reuniría con el presidente Ávila Camacho en la capital mexicana en la tarde del 17 de julio de 1945, donde en un clima de cordialidad le pondría al corriente de su parecer sobre el presente y futuro inmediato del exilio español (véase Novedades, 1945, 18 de julio, p. 1). Al término del encuentro, Negrín había logrado del presidente Ávila Camacho la concesión de la extraterritorialidad al espacio de reunión de las cortes con el propósito de cumplir con el precepto constitucional de que fuera suelo español el que albergara la sesión (véase Moradiellos, 2006, p. 549).

13 En el mismo discurso, el propio Negrín llegó a reconocer públicamente, ante aquel auditorio repleto de refugiados españoles, que hasta ese entonces "no estaban las cosas maduras para plasmar acuerdos duraderos y cualquier concierto hubiera sido efímero" (Novedades, 1945, 6 de agosto, pp. 9 y 10). 
inteligente y eficaz que recibimos del gran pueblo mejicano" (S. A., 1946, pp. 46 y 47; véase Fundación Universitaria Española, IIR/1533 [44]).

Sucintamente trazado, éste fue el contexto histórico en el que se desenvolvió del exilio republicano español durante aquellos primeros meses de 1945, que corrieron en paralelo con la derrota de las potencias del Eje y el inicio de la posguerra que tuvo, en el caso de América especialmente, una primera e importante reunión de trabajo en el castillo de Chapultepec de la ciudad de México, teniendo al presidente Ávila Camacho como su gran anfitrión. Tras aquella encarnizada guerra, y más aún después de la tragedia nuclear de Hiroshima y Nagasaki, el mundo necesitaba más que nunca sentar las bases para la construcción definitiva y duradera de la pazy, de manera muy especial, para la recuperación de la democracia como único sistema político capaz de frenar cualquier nueva invectiva totalitaria.

\section{LAS PROPUESTAS DEL EXILIO ESPAÑOL} A LOS CANCILlERES DE AMÉRICA

En este marco de diplomacia y diplomáticos, en ausencia de una invitación formal, el exilio español remitió diferentes comunicados a los cancilleres americanos y firmó otros tantos que se fueron publicando en la prensa mexicana durante el desarrollo de la cumbre. ${ }^{14}$ De entrada, la variedad y procedencia de los documentos ponían de manifiesto la fragmentación de la familia del exilio, la ausencia de una verdadera cabeza rectora y, finalmente, la presencia de una fuerte vertebración de los refugiados españoles en partidos, sindicatos y agrupaciones de todo tipo. ${ }^{15}$ Para la ocasión, y por seguir un orden, comenzaremos por el documento concebido por la Diputación Permanente de las Cortes Republicanas — sobre el papel- el

${ }_{14}$ En los prolegómenos de la cumbre de Chapultepec, el régimen franquista no ocultó su inquietud sobre las posibles repercusiones de una ruptura en cadena de los vínculos diplomáticos con los países americanos. Buena prueba de esa tensión se materializó el 26 de febrero, en pleno desarrollo de la conferencia interamericana, con motivo del acto de destrucción del escudo de la Segunda República que lucía en la fachada del edificio de la antigua embajada en México. La autoría fue atribuida a los falangistas, en especial y como autor intelectual, a Augusto Ibáñez Serrano, representante oficioso de la España franquista en México (República Española, 1945, 28 de febrero, p. 9).

15 A este respecto, he aquíun fragmento de un editorial de República Española, con motivo de un nuevo aniversario de la restauración republicana en Españay unas semanas después de celebrarse la cumbre de Chapultepec: "Es sabido que los enemigos exteriores de la República Española cohonestan siempre su fobia con el argumento, ciertamente considerable, de que los republicanos estamos tan divididos que no podemos ofrecer ninguna solución sólida. Este argumento ha constituido el ariete que más ha dañado nuestros derechos" (República Española, 1945, 15 de abril, p.2). 
único órgano institucional, aunque cuestionado por los negrinistas, aún vigente de aquella España republicana que salió del 14 de abril de $1931 .{ }^{16}$

\section{Diputación Permanente de las Cortes Republicanas Españolas}

El 20 de febrero de 1945, es decir, un día antes del arranque de la Conferencia, con las firmas de su presidente —-Diego Martínez Barrio-y de su secretario - Pedro Ferrer-, la Diputación Permanente de las Cortes Republicanas Españolas, con residencia en ese entonces en México, Distrito Federal, elevaron — verbo que se usó para la ocasión - un documento mecanografiado de tres cuartillas a la mesa de la Conferencia de Cancilleres. Su estructura formal bipartita estaba compuesta por una primera parte que reunía una compilación de ocho hechos históricos y una segunda parte con una "sugestión" para los cancilleres americanos (Archivo Histórico Genaro Estrada, Franco (1945), expediente L-E-454).

Empezando por la primera parte, los puntos iniciales servían para recordar de manera muy puntual que España, "en ejercicio de su libre autodeterminación y en acto de soberanía política”, había elegido en 1931 "un régimen republicano demócrata como su sistema político" y que había ratificado "expresamente su voluntad en febrero de 1936 al elegir su Parlamento”. A continuación, en el punto tercero, se decía que el general Francisco Franco había quebrantado su juramento de fidelidad a las instituciones republicanas, "en connivencia con los regímenes totalitarios de Italia y Alemania”, para subvertir después “el orden legal y aplastando, tras dos años y medio de guerra internacional, la determinación del pueblo español de vivir en sistema de libertad".

Como consecuencia de lo anterior, se hacía el recordatorio de la posterior imposición de "una dictadura totalitaria con el régimen falangista que coopera con el Eje en las actividades quintacolumnistas de todo el continente americano". En la misma línea, en el punto cuarto del documento, se mencionaba el desprecio del régimen franquista por las democracias y su implicación con el nazismo de Hitler, al enviar a combatir contra la Unión Soviética, "aliada de las Naciones Unidas, la famosa División Azul, cuyos jefes han sido reclamados por Rusia como criminales de guerra”.

En materia de reconocimientos, en el punto quinto se recordaba que México, la Unión Soviética, China, Checoslovaquia, el gobierno provisional de Francia, el de Yugoslavia y el de Nueva Zelanda, "países todos que han suscrito el pacto de

16 En palabras de Milagrosa Romero, la Diputación Permanente de las Cortes se consideraba "a sí misma último residuo institucional de la fenecida República" (Romero, 2005, p. 84). 
las Naciones Unidas", se habían negado a reconocer el régimen franquista, para recordar después - en el punto 6- que el 14 de agosto de 1941 el presidente estadounidense Franklin Delano Roosevelt y el primer ministro británico Winston Churchill habían firmado la Carta del Atlántico, en cuyo punto tercero se hacía expresa mención al "derecho que asiste a todos los pueblos de escoger la forma de gobierno bajo la que quieran vivir" y al deseo de "ver restablecida la soberanía y el gobierno propio de aquellos que fueron privados de ella por la fuerza”. Además de esta alusión, se hacía especial hincapié en el hecho de que este punto había sido ratificado "expresamente por todos los pueblos de Europa, por el acuerdo octavo de la Conferencia de Yalta, el día 11 de los corrientes".

Con respecto de otros países del continente americano, se hacía saber, en el punto séptimo, que el gobierno de Guatemala, "al recobrar para su pueblo el régimen de libertad", había acordado en uno de sus primeros actos "la ruptura de relaciones con el régimen del general Francisco Franco, retirando su Ministro en Madrid y entregando los pasaportes al ministro de Franco en Guatemala". ${ }^{17}$ Asimismo, en el punto 8 y último del prontuario de hechos señalados en el documento de Martínez Barrio, se decía que en la Italia liberada se estaba juzgando "en estos momentos a un general francés por haber comandado las fuerzas italianas que cooperaron al estrangulamiento de las libertades del pueblo español”, el cual había combatido "por los mismos ideales por los que combaten hoy los soldados de las Naciones Unidas durante dos años y medio”.

Con esta reseña de acontecimientos históricos, presentados de esta forma y con semejante carga conceptual —nótese, por ejemplo, que se ponía especial acento en que la Guerra Civil española no había sido nacional, sino internacional, fruto de la presencia de fuerzas militares nazi-fascistas en el conflicto armado-, la Diputación Permanente de las Cortes Republicanas Españolas se atrevía a sugerir a los cancilleres americanos reunidos en el castillo de Chapultepec, en especial tras "la creciente opinión pública americana en contra del dictador totalitario que sujeta las libertades de España", la posibilidad de "reconsiderar el problema de relaciones con aquel Gobierno", acordando, en su caso, "la ruptura general de los países que aún las mantuvieran y hayan acudido a esta Conferencia”. ${ }^{18}$

17 Con el derrocamiento de Jorge Ubico, tras 14 años de dictadura, el triunfo de la revolución guatemalteca del 20 de octubre de 19441 levó a la nueva junta revolucionaria de gobierno, integrada por Francisco Javier Arana, Jacobo Arbenzy Jorge Toriello Garrido, a desconocer el régimen franquista, rompiendo sus relaciones diplomáticas con la España del general Franco el 22 de enero de 1945.

18 En realidad, el presidente de la Diputación Permanente, Diego Martínez Barrio, había remitido el presente oficio a la Secretaría de Relaciones Exteriores de México. Según se tiene constancia, al día siguiente, 21 de febrero, 
En síntesis, teniendo a Martínez Barrio como portavoz, se hacía saber a los responsables de la política exterior de América —entre ellos, el de Estados Unidos- de la vigencia de un régimen republicano democrático en aquella España anterior al 18 de julio de 1936, resultado de un ejercicio popular de libre autodeterminación y de soberanía política, así como de la posterior presencia al mando del país del general Franco que había impuesto, tras su victoria en un largo y cruento enfrentamiento armado, una dictadura totalitaria en connivencia con las potencias del Eje, tal como lo atestiguaba el hecho del envío de la División Azul al frente ruso. Al igual, en materia de evidencias, se recordaba, primero, el desconocimiento del régimen franquista por muchos países vinculados a las Naciones Unidas; segundo, los compromisos suscritos por los tres grandes en la Carta del Atlántico y en la Conferencia de Yalta y, tercero, la ejemplaridad mostrada por países como Guatemala e Italia.

\section{Comisión Coordinadora de Entidades Republicanas Españolas}

Ese mismo 20 de febrero de 1945, la Comisión Coordinadora de Entidades Republicanas Españolas, presidida por el decano de la Facultad de Medicina de Madrid Dr. Manuel Márquez y conformada por el diplomático de la República Española Salvador Etcheverría (vicepresidente), Joaquín Noré (secretario), Serafín Aliaga (tesorero) y Fulgencio Hernández y Luis Soto (vocales), remitió también a la Honorable Junta de Cancilleres de América un largo informe de 11 páginas, dividido para la en tres grandes apartados temáticos y acompañado por una "súplica final" (Fundación Universitaria Española, SE, caja 2, expediente 17).

El primero de ellos, bajo el tenor "La República española es el régimen legal de nuestra patria” - que dejaba bien a las claras cuál de las dos Españas, a su entender, ostentaba el verdadero rango de legalidad y legitimidad en ese entonces-, partía de la concreción de una doble evidencia: la primera, que el problema de España entraba "en estos instantes en la fase más aguda de su existencia" y, la segunda, que "la crisis que allí se va a producir habrá de repercutir extraordinariamente en la nueva ordenación del mundo”. Dicho de otro modo, la más que probable derrota del nazismo ante el inexorable avance de las tropas aliadas (la capitulación de Alemania sería el 7 de mayo de 1945) debía dar origen a un nuevo tiempo de posguerra, que pasaba obligatoriamente por una reconfiguración del mapa geopolítico mundial

Pablo Campos Ortiz, en su condición Oficial Mayor, reenvió el documento a Manuel Tello, en su condición de Secretario General de la Conferencia Interamericana sobre Problemas de la Guerra y de la Paz (AHGE, Franco (1945), expediente L-E-454). 
y la consiguiente recuperación de la morfología anterior a la irrupción del nazifascismo en Europa (franquismo, incluido). En consecuencia, si España había sido la primera víctima del totalitarismo, esa misma España estaba llamada a recuperar la bandera republicana con la ayuda inexcusable de los países democráticos. ${ }^{19}$

Para reforzar estos supuestos, la comisión coordinadora recordaba que "el hecho brutal del triunfo momentáneo de las armas nazi-falangistas, ocurrido en el año 1939” no había destruido la legalidad de la República Española, la misma "que sale de España temporalmente, manteniendo con firmeza la norma política que el pueblo se dio en el ejercicio de su libre soberanía”. Así, la vigencia del status quo republicano, muy a pesar del condicionante del exilio y del gobierno franquista, quedaba recogida en el siguiente fragmento: "Es un hecho incuestionable que los Poderes organizados de la República no han hecho jamás dejación de la soberanía” y, por el contrario, "mantienen la legalidad republicana, aun alejados del territorio de la Patria”. Precisamente, estos poderes se habían visto obligados a salir de España "por la violencia brutal de las armas nazi-fascistas que apoyaron decididamente a los traidores de la Patria”.

Implícitamente, la misma contundencia del argumento dejaba entrever que, ante el mundo, los republicanos españoles carecían del aval jurídico necesario, primero, para ser reconocidos por la comunidad internacional aliada y, segundo, para asumir el protagonismo político con vistas a un inminente escenario que contemplase la caída de la dictadura franquista y, por consiguiente, el retorno a España de las instituciones republicanas.

Frente a esta sustentación jurídica en torno a la vigencia, legalidad y legitimidad de la República española, por más de que ésta se encontrara padeciendo el exilio y la gran mayoría de los refugiados la dura diáspora, el segundo de los apartados del memorándum de la Comisión Coordinadora de Entidades Republicanas Españolas iba encaminado a hacer una precisa caracterización del régimen del general Franco, bajo el siguiente y elocuente tenor: "El terror franquista continúa ensangrentando a España después de siete años de terminada la guerra en el territorio nacional". Así, y si en ese entonces Europa seguía padeciendo la crueldad y devastación de la guerra mundial, al sur de los Pirineos la represión planificada y sistemática en

19 En portada, con estas palabras lo explicaba República Española, uno de los periódicos del exilio: "Pero como el empeño de los señores de la guerra era imprescriptible, España vio sus tierras invadidas por fuerzas regulares alemanas e italianas que acudieron en auxilio de los militares traidores, de la aristocracia terrateniente, de los prelados serviles, con el pretexto de asegurar el orden cristiano contra el comunismo" (República Española, 1945, 15 de abril, p. 1). 
contra del bando perdedor seguía acumulando muertes por doquier. El franquismo seguía implacablemente su cruzada contra el enemigo.

Las primeras líneas no podían ser más expresivas en cuanto al nivel de violencia y castigo que se venía padeciendo en España a unos años de haberse dado por terminado el conflicto armado. He aquí el siguiente fragmento: "Si tuviéramos que reproducir ante esta Honorable Asamblea de Cancilleres una información pormenorizada de los actos de terror que desde que finalizó la guerra de España se llevan cometidos dentro de la Patria, habríamos de llenar centenares de cuartillas que causarían pesadumbre y horror a los que las leyesen”. Líneas más abajo se puntualizaba que "el régimen carcelario [era] algo pavoroso [y] un suplicio dantesco".

Para ello, entre otros, se daba cuenta del testimonio de un fugado "de las prisiones de Franco, que vivió horas de espanto indescriptible”, quien rememoraría después que "la vida de hacinamiento existente en la totalidad de los penales [y] la carencia absoluta de higiene originan considerable número de enfermedades infecciosas" y que la deficiencia del sistema alimenticio venía provocando y extendiendo "la tuberculosis en cifras aterradoras". Así, la pregunta siguiente tenía un claro tono de denuncia y hasta de acusación, invocando a todos y cada uno de los cancilleres americanos a responder a la siguiente pregunta: "Después de oír estos relatos, ‘habrá demócratas que aún parlamenten con Franco y sigan considerándole humano?”.

En la misma línea argumentativa, el último de los apartados del informe se enfocaba en demostrar que el régimen franquista no era únicamente una amenaza real para el republicanismo español, presente tanto dentro como fuera de España, sino además un serio y verdadero problema para los países democráticos, también del continente americano. Para la ocasión, el entrecomillado era contundente desde la redacción misma del enunciado: "Peligro del falangismo para América, que se introduce en el continente con el famoso Consejo de la Hispanidad". ${ }^{20}$

A este respecto, hay que recordar que, bajo un talante vocacional de imperio, el franquismo hizo de la Hispanidad una bandera propagandística de influencia y penetración ideológica en aquellos países de la América hispana, en otro tiempo subordinados a la España monárquica por el vínculo colonial (Delgado, 1988, p. 10;

20 El Consejo de la Hispanidad fue una institución fundada el 2 de noviembre de 1940 por orden estricta del general Franco, teniendo como metas prioritarias el fomento y prestigio de la herencia hispánica en Américay Filipinas, así como el combate, a través de una intensa apuesta editorial y un generoso despliegue de medios propagandísticos, de la leyenda negra antiespañola. No hay que olvidar que Franco, autodenominado "Caudillo de España por la gracia de Dios", se hizo pasar como un nuevo emperador, emparentando en línea directa con reyes como Carlos I o Felipe II, que bajo su cetro gobernaron un imperio donde no se ponía el sol (véase, por ejemplo, Colom, 2006, pp. 43-82). 
Espadas, 1987, p. 28). Como premisa rectora, bajo el amparo de la Madre Patria, había que reconstruir un tejido común sobre el sustento de la tradición, la cultura, el idioma y la religión católica, en suma, a través de una mística sustentada en los tradicionales lazos culturales y espirituales.

Por lo tanto, presentado como el gran cruzado vencedor contra el maligno comunista, el general Franco pasaba a ser la referencia modélica para todos aquellos que quisieran construir en el continente americano un futuro desde la espiritualidad católica, entendida ésta como el gran dique preventivo contra ideologías como el liberalismo, el socialismo o el comunismo, así como contra el protestantismo o la masonería. En palabras de Rosa Pardo, "el nacionalismo español contemporáneo había dejado que América se incorporase a la mitología histórica patria” (Pardo, 1995, p. 31).

Por eso, esta comisión coordinadora quiso poner un acento especial en la idea de que el Consejo de la Hispanidad venía sembrando sistemáticamente una "semilla letal" en el hemisferio que, a todas luces, "irá dando sus desdichados frutos, si no se toman urgentes medidas de saneamiento". Para ello se hacía constar que, "infortunadamente, ya hemos visto cómo la Falange, utilizando al igual que el nazi-fascismo los canales diplomáticos, los centros culturales o el Consejo de la Hispanidad, abrió brecha profunda sobre el territorio de la República [de] Argentina, en donde germinó con asombrosa fecundidad la idea fascista".

Como se ha dicho más arriba, el cierre de este largo informe se hizo, tal como era de esperar, presentando un ruego petitorio — en este caso, a modo de súplica- para que los cancilleres americanos intercediesen ante sus respectivos gobiernos, con el fin de propiciar "la urgente ruptura de relaciones diplomáticas con el régimen de Franco". Con esta demanda, el republicanismo del exilio mostraba su "vehemente deseo" de hacer algo más por la causa de la democracia universal, "a la que estamos ligados por los vínculos de nuestra sangre que derrama heroicamente desde el año 1936 sobre todos los campos de batalla, de igual modo que lo hacen hoy los valientes defensores de la Libertad".

$\mathrm{Al}$ igual, aunque ésta a modo de postdata, se integraba la siguiente reflexión, no exenta de un manifiesto tono de denuncia, tan habitual en todos y cada uno de los comunicados que se firmaron en el marco de la cumbre de Chapultepec: "Estimamos que un hecho tal daría amplia satisfacción a la conciencia democrática española, que se ha visto hasta hoy abandonada injustamente por la mayoría de los países que tuvieron una concepción equivocada de nuestro trágico problema”. 


\section{Otras organizaciones españolas y su petición de justicia}

El 26 de febrero de 1945, El Nacional volvía a ser el pórtico de difusión pública de un nuevo comunicado del exilio, en este caso elaborado bajo el beneplácito de una larga lista de organizaciones españolas y republicanas con el propósito de "pedir justicia a la Conferencia Interamericana de Cancilleres" (El Nacional, 1945, 26 de febrero, p. 7). Este periódico oficial mexicano, hay que mencionarlo antes de reproducir el texto, significaba para sus lectores que el mensaje tenía un "doble valor", porque lo suscribían "la mayoría de las organizaciones españolas radicadas en México", entre ellas, sindicatos, partidos, agrupaciones o asociaciones de distinto tipo (véase el anexo 1).

En un escueto, pero preciso comunicado, las organizaciones firmantes - "que agrupan a las más importantes fuerzas políticas y sociales españolas, radicadas en esta Ciudad" - hacían una interpretación de "los sentimientos unánimes del antifranquismo español", y se tomaban la licencia de manifestar a la Conferencia de Cancilleres que el régimen franquista era "un elemento de perturbación contra los planes de paz, democracia y desarrollo del progreso de este Continente".

Para la ocasión, poniendo como ejemplo "las posiciones adoptadas" por México y Guatemala -ambos países contrarios al franquismo y sin afán alguno de mantener relaciones oficiales con el gobierno franquista-, se solicitaba la elaboración y firma de una declaración conjunta, "señalando a los Gobiernos representados la conveniencia de una ruptura de relaciones con el franquismo y el reconocimiento del Gobierno legítimo de la República y demás instituciones legales republicanas". De este modo, en el marco de una guerra mundial contra el totalitarismo nazi-fascista, aún inconclusa, dicha ruptura habría de representar, en opinión de los firmantes, "un acto de justicia con el pueblo español", el mismo que venía ostentando su condición de haber sido la "primera víctima de la agresión nazi-fascista".

\section{Otros comunicados del republicanismo español en el exilio}

Como se ha dicho más arriba, la negativa de la Comisión de Iniciativas de abordar el problema español en la Conferencia de Chapultepec provocó que la prensa mexicana se convirtiera en una caja de resonancia, principalmente El Nacional, para hacer públicas las demandas provenientes de diferentes sectores del exilio español, la mayoría de ellos radicados en México. Así, el 24 de febrero del 45, en pleno desarrollo de la reunión de Chapultepec, diversas personalidades - "representativas de amplios sectores del republicanismo español" - publicaron un comunicado en este 
diario oficial en el que manifestaban su deseo de que "esa honorable Conferencia, coincidiendo con la actitud de algunos gobiernos participantes en la misma, acordara una declaración común aconsejando a los gobiernos representados la ruptura de relaciones con el régimen franquista y el reconocimiento del Gobierno legítimo de la República española". Entre los signatarios del documento se encontraban personajes del exilio como Antonio Velao, Vicente Uribe, José Moix, Segundo Blando y Tomás Bilbao (todos ellos, ministros republicanos); Ramón Lamoneda (secretario del Partido Socialista Obrero Español) y José Rodríguez Vega (secretario general de la Unión General de Trabajadores de España) (El Nacional, 1945, 24 de febrero, p. 6).

Tan solo unos días después, el 28 de febrero, de nuevo El Nacional publicó en esta ocasión un memorándum de la Comisión de Ayuda a la Junta Suprema de Unión Nacional Española ${ }^{21}$ en el cual se refutaba el argumento que había dado sustento a la decisión de sacar el problema español de la agenda de los cancilleres, bajo el entendido de que el planteamiento del caso de España "no puede desligarse de los actuales problemas del mundo y menos aún de los problemas genuinamente americanos" (El Nacional, 1945, 28 de febrero, p. 7). En consecuencia, se hacía la petición expresa de que los responsables de la política exterior de los países americanos se pronunciasen de forma unánime por "la ruptura de relaciones diplomáticas y económicas de los países, que en ella participan, con el régimen de Francisco Franco". Y esto así, porque el rompimiento de dichas relaciones habría de constituir "la mejor ayuda que se puede prestar en estos momentos a un pueblo indomable que luchó y lucha valientemente por la causa de la democracia" y, al mismo tiempo, una positiva y eficaz aportación a la causa de la paz perdurable y definitiva, en donde los malvados no puedan tener asiento".

En materia argumentativa, los firmantes denunciaban que América Latina ya era para ese entonces, y aún sin terminar la Segunda Guerra Mundial, "el principal campo de operaciones de la Falange", en especial porque, en su opinión, el falangismo seguía constituyendo, a través de su política exterior, "la cabeza de puente del nazi-fascismo desplegado en los países hispanoamericanos, utilizando las

\footnotetext{
${ }^{21}$ La Junta Suprema de Unión Nacional Española fue una organización antifranquista creada en Francia en 1942 a instancias del Partido Comunista de España, con el objeto de agrupar fuerzas para luchar contra la dictadura franquista. A pesar de su ambición totalizadora, de ésta quedaron excluidos personajes como Prieto o Araquistáin, en suma, los más acérrimos anticomunistas. Fue disuelta en junio de 1945. De algún modo, operó como antítesis de la Junta Española de Liberación (JEL). Como señala Pedro Angosto, "la exclusión de los comunistas [de la JEL], condicionada por la experiencia de la Guerra Civil y por el anticomunismo de algunos países aliados, era estratégicamente hábil, pero suponía incentivar un elemento disgregador de primer orden en un momento en el que podría haber sido más útil la unidad de todos" (Angosto, 2009, p. 260. Véase también Romero, 2005, pp. 228-234).
} 
relaciones históricas, la lengua y las múltiples y profundas actividades que tenemos con nuestros hermanos de América para realizar objetivos concretos de hitlerismo, es decir, de nazi-fascismo internacional".

Para esta comisión de ayuda, los objetivos operativos de este falangismo franquista se resumían en los siguientes: 1) dividir a las naciones americanas y crear fricciones entre éstas; 2) originar graves problemas internos dentro de los países de América Latina; 3) utilizar el falso señuelo de una hispanidad deformada para destruir la solidaridad política y económica de las naciones americanas; 4) utilizar los más sutiles métodos de espionaje al servicio del nazi-fascismo, incluso a través de las embajadas y legaciones; 5) organizar una verdadera quintacolumna en los países hispanoamericanos para crear pugnas entre sí y muy especialmente con la gran democracia norteamericana; 6) impedir un bloque democrático en el continente, y 7) procurar el mantenimiento de regímenes de dictadura en las tierras libres de América.

Como se observa, el exilio español hacía un especial hincapié en los graves problemas internacionales que podía generar la presencia en España de un régimen como el franquista, entre ellos, la desestabilización interna de los países americanos, la ruptura del espíritu panamericanista, la hispanidad como coartada, el espionaje nazi-fascista, la penetración del quintacolumnismo o la acechanza de dictaduras como la que en ese entonces había arraigado en Argentina. En pocas palabras, Franco y el régimen franquista no eran únicamente los principales enemigos del republicanismo español, sino también una amenaza cierta para los países de América.

Ese mismo 28 de febrero, desde la capital mexicana, Salvador Etcheverría Brañas, abogado, político y militante gallego de Acción Republicana, también quiso sumarse a la lista de autores que escribieron en torno a la cumbre de cancilleres americanos, redactando para la ocasión un documento de tres cuartillas mecanografiadas bajo el tenor "El clima de la Conferencia" (Fundación Universitaria Española, SE, caja 2, expediente 17). ${ }^{22}$ En un tono descriptivo, sus primeras palabras fueron para referirse a la razón primera y última que había animado la celebración de tal reunión de mandatarios en la ciudad de México, fundamentalmente concebida para "solucionar los problemas latentes de la guerra, como los de la paz que se avecina"

\footnotetext{
22 Salvador Etcheverría Brañas era un hombre que atesoraba una vasta experiencia diplomática. Para entonces, ya había sido canciller de la embajada de España en Cuba (1937), cónsul de España en Veracruz (1937-1938) y encargado de Negocios de España en Ciudad Trujillo, Santo Domingo (1938-1941); más adelante, tendría diversas funciones para laSegunda República Española en el Exilio como encargado de Negocios en Guatemala (1947), secretario en funciones de la embajada española en México (1950), ministro plenipotenciario y director general de los Servicios Consulares de la embajada en México (1953), así como ministro de Información, Propaganday Archivos, ysecretario del Consejo de Ministros (1955) (Fundación Universitaria Española, SE, caja 1, expediente 10).
} 
y para "resolver determinadas cuestiones que son, evidentemente, de singular importancia en esta hora crucial".

Entrando en materia, hablando de forma genérica en nombre de los republicanos españoles - "que también somos ciudadanos del mundo"-, Etcheverría precisó que, desde la inauguración de la Conferencia de Chapultepec, venía observando con atención "las deliberaciones que se pusieron sobre el tapete", eso sí, "con el ánimo decidido de hacer por nuestra parte algo útil para el futuro de la humanidad, sangrada implacablemente por el enemigos del bien". Y, en materia de utilidades, con el fin de "hacer algo bueno para los demás", se permitía recordar a los congregados, "con emotiva insistencia," el peligro que suponía "dejar para mejor ocasión tratar el caso de España”.

En asunto de argumentaciones, Etcheverría trajo a colación las últimas informaciones recogidas en la prensa, ya "extendidas por el mundo", dando cuenta de "la brutal represión llevada a cabo por Falange el día 27 de febrero", así como "la escandalosa manifestación nazi-falangista organizada en Madrid para ratificar los siniestros propósitos de la tiranía de Franco". ${ }^{23}$ Ambas evidencias, en opinión de este político exiliado, no eran sino "el último botón de muestra que ofrecen los fanáticos agentes del Hitler, quienes persisten implacablemente en martirizar a un pueblo que continua la lucha heroica por la recuperación de sus libertades".

De cualquier modo, más allá de diagnósticos y evidencias, Etcheverría no ocultó su talante pragmático y realista al aseverar que los republicanos españoles del exilio "de antemano sabíamos que el caso de España quedaba fuera de la Agenda en esta ocasión". Y, a pesar de ello, "nos interesaba profundamente quedar apartados de la responsabilidad histórica que semejante error nos pueda alcanzar en un mañana que ya no vemos muy lejano" (Fundación Universitaria Española, SE, caja 2, expediente 17). Por consiguiente, el exilio se vio en la necesidad de "pulsar el ambiente de comprensión y de amistad con que cuenta nuestra causa, después de los infortunios padecidos". En un arrebato de cierto optimismo, reconoció y declaró que "los supuestos se confirmaron exactamente para nuestra ventura", hasta el punto de que, una vez más, "nuestro sentimiento" había sido recibido "con cariño acendrado y con clara visión del porvenir", propiciando "el clima político necesario para los fines comunes que interesan a la Democracia universal”.

\footnotetext{
23 La prensa española se hizo eco de las "más de trescientas mil personas de las todas clases sociales" que el 27 de febrero se habían sumado "al duelo de la Falange en el entierro de los camaradas vilmente asesinados el domingo por los comunistas". Así, "no hemos presenciado, jamás, un espectáculo tan hondo, tan sincero y tan penetrante como el que ayer ofreció el pueblo de Madrid, al expresar su dolor en el entierro de los dos falangistas asesinados por el terrorismo comunista" ( $A B C, 1945,28$ de febrero, p. 7).
} 
Secundando el mismo tono de confianza, Etcheverría también se refirió a "la finísima sensibilidad de los representantes de la Democracia Americana” y a su capacidad por captar "íntegramente este nuevo episodio el drama español", con el fin de que pudieran sacar "humanas conclusiones para evitar su trágica repetición”. En consecuencia, este diplomático republicano depositaba sus esperanzas en "la reacción política y sentimental de los muchos delegados con quienes nos fue dable hablar", que obligaba a los exiliados españoles a creer "que no va a pasar mucho tiempo sin reconsiderar el peligro que dejamos señalado". ${ }^{24}$

En la misma línea, recordó también que la concepción que los republicanos del exilio tenían con respecto del "problema mundial" la habían expuesto "con crudo realismo miles de veces" y que ésta era coincidente "con la totalidad de las democracias que luchan por la supervivencia”. De ahí que, a unos años de haberse acabado la Guerra Civil española, se imponía "por bien de todos" la necesidad de "acelerar el procedimiento y acortar los plazos", porque "nada se va ganando con mantener el foco de infección, que cualquier día puede extenderse violentamente sobre el cuerpo vigoroso de América que, si bien está limpio hoy de toda contaminación, puede acusar bruscamente los síntomas de la sombría enfermedad, si se olvida la profilaxis oportuna”.

Por eso, como idea central en el corpus de su documento, este político gallego dejó escrito el siguiente entrecomillado a modo de conclusión y hasta de advertencia: "Cuanto más pronto se produzca el hecho de la ruptura de relaciones diplomáticas con Franco, tanto más fácil será la tarea que resta por hacer, para afianzar la victoria y la paz que el mundo necesita”. Por eso, Etcheverría creía que bien valía la pena meditar y "seguidamente romper".

\section{VALORACIONES DEL EXILIO ESPAÑOL TRAS la Conferencia de Chapultepec}

Concluida la Conferencia de Cancilleres de Chapultepec, las declaraciones de los diferentes líderes del exilio republicano español tuvieron, como era previsible,

\footnotetext{
24 Sin duda, también se desarrolló otra cumbre de cancilleres entre bastidores. A la prensa saltó el rumor de la constitución de un bloque de países, formado por Cuba, Guatemala, Colombia y Haití, para abordar el problema del rompimiento con el gobierno de Franco una vez concluida la conferencia. A su vez, hubo cancilleres que se manifestaron partidarios de esta acción, entre ellos, Enrique MuñozMeany (Guatemala), Alberto Lleras Camargo (Colombia),Jacobo Varela (República del Uruguay), Camilo Ponce Enríquez(Ecuador), Gustavo Cuervo Rubio (Cuba), Gustavo Chacón y Roberto Montenegro (Bolivia) (Excélsior, 1945, 1² de marzo, p. 1).
} 
un acentuado tono de decepción y aun de desencanto por los parcos resultados obtenidos en una reunión interamericana en la que se habían depositado muchas esperanzas de éxito. Al menos eso es lo que se hizo creer, a pesar de que, desde el primer día, la Comisión de Iniciativas aceptara por consenso no integrar en la agenda de trabajo el problema español. ${ }^{25}$ El periódico Adelante, órgano de difusión del Partido Socialista Obrero, dirigido por el tipógrafo y periodista zaragozano Manuel Albar, publicó este fragmento: "El caso de España, sangrante, monstruoso, concreción de violencias y de crímenes, afirmación cínica del despotismo totalitario, tenía bastante volumen para no pasarlo por alto, para no desconocerlo o desdeñarlo" (Adelante, 1945, 15 de marzo, p. 4).

No se oculta que, de entrada y para la pertinencia de su causa, no hubiera sido un asunto menor que, de manera unánime y en una cumbre como la de Chapultepec, los países del continente americano - Estados Unidos, entre ellos- hubieran tomado la firme decisión de romper todo vínculo diplomático con la España del general Franco, en especial a pocos días de celebrarse en San Francisco la gran Conferencia internacional, donde habrían de participar otro tipo de países como la Unión Soviética. ${ }^{26}$

Esta idea de la ruptura unánime fue también la intención reclamada por parte de la Federación de Organismos de Ayuda a los Refugiados Europeos (FOARE), en "un atento mensaje" a Mr. Edward Stettinius, presidente de la delegación norteamericana en dicha Conferencia, en el que le expresaban los peligros que representaba el hecho de que el franquismo continuase "su obra perturbadora en América". Tras esta observación, le pedían su apoyo expreso a una declaración conjunta en la que se recomendase "a los gobiernos representados" la ruptura con dicho régimen franquista y el reconocimiento del Gobierno legítimo de la República Española, "acuerdo que sería un acto de justicia a la lucha del pueblo español, primera víctima a la agresión nazi-fascista” (El Nacional, 1945, 24 de febrero, p. 6). ${ }^{27}$

\footnotetext{
25 Vicente Lombardo Toledano, uno de los líderes del obrerismo mexicano y presidente de la Confederación de Trabajadores de América Latina (CTAL), organización que se hizo presente en la cumbre de Chapultepec exponiendo diferentes propuestas, no tuvo dudas al afirmar que la República española, ante la falta de respuesta cabal de América, habría de recordar esta conferencia de cancilleres "con tristeza y amargura" (Lombardo, 1945, 11 de marzo; Lombardo, 1945a. Véase también Herrera, 2013, pp. 215-231).

26 Sobre la evolución del comportamiento de los países latinoamericanos en las Naciones Unidas con respecto del problema español, véase Sola Ayape, 2015b, pp. 65-95.

27 En este sentido, es importante subrayar que en esta cumbre de Chapultepec, Estados Unidos tuvo un especial cuidado en abordar asuntos estrictamente continentales, abortando toda posibilidad de tratar el caso español, reservado por sus implicaciones a la conferencia internacional que se habría de celebrar días después en San Francisco. Ésta fue una de las premisas que los tres grandes acordaron en la cumbre de Yalta tan sólo unos días antes, concretamente a principios de ese mes de febrero.
} 
A decir verdad, no se oculta que, de haberse logrado este propósito, aquello hubiera sido no sólo un reconocimiento explícito a la legalidad y legitimidad de aquella España peregrina, sino también un paso firme hacia adelante con vistas a un previsible escenario donde la caída del franquismo habría de significar el inmediato retorno a la tierra perdida y la consiguiente restauración de la bandera tricolor republicana. Pero aquel asunto de expectativas, muy pronto se convirtió en capítulo de frustraciones (Sola Ayape, 2013, pp. 57-74).

$\mathrm{Al}$ respecto, hay que decir que una de las figuras más buscadas por los corresponsales extranjeros y los redactores de prensa mexicana fue Álvaro de Albornoz Liminiana, miembro de la formación política Izquierda Republicana y presidente de la Junta Española de Liberación (JEL), que desde 1943 venía aglutinando a una parte importante de la familia republicana del exilio. ${ }^{28}$ Recordemos que la JEL fue constituida en noviembre de 1943 por un grupo de formaciones políticas en el Centro Republicano Español de la Ciudad de México. Detrás de su gran propósito se encontraba la necesidad de participar, de una u otra forma, en las conferencias internacionales que venían celebrando las grandes potencias sobre el futuro de la guerra y la posguerra mundiales. Entre sus principios constitutivos, destacaban la formación de un gran pacto de unidad entre las fuerzas políticas republicanas para derrocar a "la tiranía falangista impuesta, merced al auxilio armado de potencias extranjeras", cerrando el "paso a la monarquía”, todo ello bajo la "más absoluta fidelidad" a los principios de la Constitución republicana del 9 de diciembre de 1931 y por el establecimiento de un régimen genuinamente democrático en España conforme a los trazos de la Carta del Atlántico. En palabras de Álvaro de Albornoz, "nosotros queremos colocar a la Junta Española de Liberación en situación conveniente para que en una coyuntura propicia de la política internacional pueda ser el instrumento de la restauración de la República española" (Albornoz, 1944, p. 22).

Al término de la cumbre, en su comparecencia ante los medios de comunicación, a cuyo evento asistieron también otros miembros directivos de la JEL como Indalecio Prieto, Félix Gordón Ordás, Antonio María Sbert o José Mascort, así como un gran número de artistas, intelectuales y diputados españoles, este líder republicano, que después acabaría siendo presidente del gobierno de la República en el exilio desde agosto de 1947 hasta julio de 1951, lamentó profundamente y

28 La prensa mexicana se hizo eco de los diferentes pormenores que acompañaron a la formación de la JEL (véase El Nacional, 1943, 26 de noviembre, p. 2, y Excélsior, 1943, 24 de diciembre, pp. 10 y 11). 
sin tibiezas que el problema de la España republicana no se hubiera tratado en la Conferencia de Cancilleres. ${ }^{29}$

Sus primeras palabras tuvieron este nivel de elocuencia: "Nuestra España, la democrática, como el personaje famoso de nuestro teatro - el convidado de piedra-, se filtró por las paredes del Castillo como un recuerdo y una acusación", para después hacer la siguiente declaración de intenciones: "Los republicanos españoles [...] lo único que piden es el repudio a un régimen que constituye el más grande oprobio a la libertad internacional por que luchan las Naciones Unidas" (Excélsior, 1945, 4 de marzo, p. 6). A decir verdad, el matiz era importante, porque una cosa era solicitar el rompimiento unánime de relaciones diplomáticas y otra, bien distinta, el repudio a un régimen como el franquista por más de que éste representase un oprobio a la libertad internacional. Era evidente que la mesura en las declaraciones era una clara estrategia de la JEL en vísperas de la celebración de la gran conferencia internacional de San Francisco, también en presencia de los países americanos, donde, dicho sea de paso, logró "uno de los mayores éxitos para el imaginario colectivo de los antifranquistas” (Yuste de Paz, 2005, p. 45).

De cualquier modo, el acto de presencia del exilio español en la Conferencia Interamericana, aunque sólo tuviera un carácter testimonial, sirvió, en opinión del orador, para ir avanzando y concretando las gestiones pertinentes con "prominentes funcionarios norteamericanos", con el fin de lograr las "facilidades para desplazarse a San Francisco y mantener contactos con países que están dispuestos a convertirse en abanderados de la causa de la restauración republicana”. Acto seguido, sus palabras últimas sirvieron para hacer públicos dos importantes anuncios: el primero, sobre el proceso abierto de elaboración de "un documento de la causa republicana, en el que laborarán tratadistas de fama internacional” para su presentación en la Conferencia de San Francisco y, el segundo, sobre "el propósito de los directivos de la Junta" de trasladarse a Francia para realizar una "labor efectiva, no para patrocinar empresas de aventuras".

A decir verdad, tal documento no fue otro que aquel que intitularon La Junta Española de Liberación ante la Conferencia de San Francisco de California. Por medio del mismo documento, el exilio español, o cuando menos aquella parte de éste representada en esta junta, apeló a la "responsabilidad histórica" que debían

29 En palabras de Luis Hernando Noguera, la JEL justificó su presencia en la cumbre de cancilleres a través de comités parlamentarios, aunque siempre cuidando las formas, ya que, una vez descartada la problemática española, "toda propuesta foránea podía ser despreciada, lo que sería un grave precedente para las intenciones españolas" (Hernando, 2013, p. 68). 
asumir los países aliados para que, a diferencia de lo acontecido en el castillo de Chapultepec, tuvieran presente en sus discusiones y deliberaciones el "caso especialísimo de España”, en el entendido de que, primero, España había sido la primera nación en el viejo continente en "conocer los efectos horribles de la guerra totalitaria" y, segundo, el franquismo se había instaurado "mediante una cruenta guerra civil favorecida y alentada por la Italia del duce y la Alemania del führer". ${ }^{30}$

En cuanto a la segunda noticia avanzada, Álvaro de Albornoz ponía a las claras el sentir del exilio de trasladar su centro de operaciones a París, no sólo por la decepción que había supuesto para la defensa de su causa el comportamiento de los cancilleres americanos reunidos para tratar sobre los problemas de la guerra y la paz, sino también por la acuciante necesidad de ser operativos en un país aliado y además fronterizo con España. En este sentido, tal anuncio fue el presagio de lo que sucedería unos meses después con motivo de la reconstrucción de las instituciones republicanas en agosto de 1945 en la capital mexicana, cuando la nueva República de Diego Martínez Barrio y el consiguiente gobierno de José Giral fijaron su residencia en París en febrero de $1946 .{ }^{31}$

En la misma línea, otro de los exiliados españoles que hizo su particular valoración sobre el balance de la Conferencia de Chapultepec fue el bilbaíno Vicente Lascurain Fernández por medio de la publicación en República Española de un artículo intitulado "La Conferencia de Cancilleres" (República Española, 1945, 15 de abril de , p. 3). ${ }^{32}$ En el mismo, en sus primeras estimaciones, aludió a las "circunstancias" de "orden funcional" que habían condicionado la agenda de trabajo de los cancilleres americanos, en el sentido de "no tratar ningún problema que previamente no hubiera sido incluido en el temario".

30 La Junta Española de Liberación ante la Conferencia de San Francisco de California, 1945, México, Ediciones DEI, 32 pp. Véase también Fundación Universitaria Española, R.43. Este documento del exilio español fue el soporte conceptual que inspiró el discurso del delegado mexicano Luis Quintanilla, el mismo presentó ante la Conferencia de San Francisco el 19 de junio de 1945. A la postre, su intervención fue determinante para que se aprobase su propuesta de que la España de Franco quedase fuera de las Naciones Unidas por sus implicaciones con el nazifascismo (al respecto, véase Sola Ayape, 2009, pp. 153-159).

31 En diciembre de 1945, José Giral, en su condición de presidente del gobierno republicano, solicitó al Ejecutivo francés el permiso para afincarse en París. Tres meses después, las autoridades galas le concedían un estatuto especial que aseguraba el definitivo establecimiento en Francia de las instituciones republicanas del exilio (Alonso, 2004, pp. 49 y 50; Cabeza, 1997, p. 44 yss.).

32 Licenciado en Filosofía y Letras por la Universidad de Salamanca, Lascurain formaba parte del Secretariado Juvenil de la Comisión Ejecutiva del PSOE al terminar la Guerra Civil. A su llegada a México, en mayo de 1942, formó parte del sector negrinista del PSOE y colaboró como periodista en periódicos capitalinos como La Prensa y Prensa Gráfica. 
Al respecto, en un tono comprensivo, el autor hizo mención al "cuidado extraordinario en no tratar problemas extra continentales que, por su propia significación mundial, caen dentro de la órbita de la próxima reunión de San Francisco de California, donde inevitablemente se abordará el caso de España y otros similares". No hay que olvidar, como se ha dicho más arriba, el acuerdo establecido en Yalta entre los tres grandes en el sentido de no suscitar, hasta la reunión en San Francisco, ninguna polémica en torno a aquellos temas que pudieran despertar discrepancias ni mucho menos afirmar compromisos separados sobre su posible solución. Y huelga decir que el problema de España era uno de ellos. ${ }^{33}$ De cualquier modo, Lascurain reconoció que, en lo concerniente a la España del exilio, "lo que hace unos años era simplemente una cuestión enojosa de rojismo, hoy se ha convertido en un asunto que apasiona, que se estudia con particular cariño".

Sin embargo, frente a su percepción de apasionamiento y cariño, es importante poner de relieve el ejercicio de autocrítica que hizo Lascurain, en especial haciendo énfasis en las formas usadas por los representantes del exilio republicano español a la hora de abordar su problemática en la para entonces conclusa cumbre de Chapultepec. A su modo de ver, todo había quedado reducido a "un acto protocolario, frío, desprovisto de pasión por la causa que se defiende, o a pequeñas fiestas íntimas en las cuales campa un regocijo que nunca se traduce en hechos". Así, a su entender, durante los días que duró la Conferencia, el republicanismo español del exilio había dado un "espectáculo de dispersión de fuerzas y de métodos absurdos de trabajo desplegados ante los Cancilleres", haciendo además un "alarde demagógico", confundiendo, a la postre, "una reunión internacional con un mitin en el Puente de Vallecas, y creyendo que algo se adelanta con repartir profusamente hojas más o menos clandestinas que los delegados sumaban pacientemente a los centenares que diariamente recibían y no leían".

En suma, tras esta elocuente caracterización, no sólo había faltado coordinación, sino también la "presentación de una unidad que en el fondo existe, puesto que, exceptuando media docena de renegados, la emigración no ha perdido el sentimiento hasta el punto de no tener un criterio idéntico cuando se trata ganar una batalla a Franco". No obstante, Lascurain lamentaba la falta de "una campaña coordinada que debió iniciarse hace mucho tiempo para lograr que los delegados trajeran mandatos concretos sobre el problema" y, en consecuencia, una tarea de

\footnotetext{
33 La reunión de los tres grandes en Yalta despertó una gran ilusión entre exiliados españoles porque se llegó a la conclusión de que había que ayudar conjuntamente "a los pueblos de los Estados europeos liberados o de los Estados europeos que fueron satélites del Eje” (Fundación Universitaria Española, EH, expediente 2-12).
} 
preparación entre los propios republicanos [...], de trabajo efectivo, alejado de alardes verbalistas improcedentes o de frío cumplimiento de una misión desagradable".

Finalmente, como cierre de su artículo, Lascurain hizo un exhorto a toda la familia del exilio, en el sentido de que "somos nosotros los que tenemos que ganar nuestra propia libertad", ya que "no es justo esperar que los demás hagan trabajos y arrostren responsabilidades que nosotros rehuimos". En su opinión, de la Conferencia de Chapultepec "nos queda esta gran lección" (República Española, 1945, 15 de abril, p. 3).

\section{EL DESENCANTO DEL EXILIO: A MODO DE FINAL}

El 3 de marzo de 1945, aún sin terminar la Conferencia de Chapultepec, el periódico España, órgano de difusión de la JEL, adelantó un editorial con el fin de hacer su particular balance de aquel encuentro entre cancilleres en la capital del México del general Ávila Camacho. Reconociendo el hecho de que "el caso de nuestra patria” no había podido abordarse en la presente Conferencia Interamericana, "dedicada exclusivamente a problemas americanos", esperaban, sin embargo, que no fuese "eludido en la Conferencia de San Francisco de California, donde van a tratarse problemas mundiales”. Asimismo, la valoración final no estaba exenta de un ostensible desencanto, "porque si España no está en América, aunque dejara en este Continente huella profunda e imborrable, está desde luego en el mundo" (España. Órgano de la Junta Española de Liberación, 1945, 3 de marzo, p. 1).

Si bien, bajo el apremio de ir visualizando el futuro e inminente tiempo de posguerra, se habían realizado varias conferencias internacionales como las de Moscú (octubre de 1943), El Cairo (noviembre de 1943), Teherán (noviembre de 1943) y la última en Yalta (febrero de 1945), todas ellas habían contado con la participación de las grandes potencias como Estados Unidos, Gran Bretaña y la Unión Soviética. Y, si en la mayoría de ellas, el exilio se había hecho presente a través de comunicados para los convocantes o para ser difundidos en la prensa, ${ }^{34}$ la cumbre de Chapultepec era la primera vez en que los países americanos se reunían para abordar la problemática de la guerra y de la paz, tan solo unos días después de la cumbre de Yalta.

\footnotetext{
34 Véase, por ejemplo, el documento titulado "La Junta Española de Liberación ante la declaración de Crimea, 13 de febrero de 1945". En el mismo, se daba por hecho que, con el apoyo de las grandes potencias aliadas, "el problema español podrá ser resuelto sin nuevos derramamientos de sangre” (Excélsior, 1945, 15 de febrero, p. 15).
} 
En este contexto, el exilio español vio en la Conferencia de Chapultepec el escenario ideal para la reivindicación de su causa y para la obtención del apoyo de los países del continente americano, entre otros, de unos Estados Unidos que seguían liderando la bandera aliada en el frente de batalla contra el Eje. Además del ejercicio de responsabilidad de sus líderes políticos y de la necesidad de demostrar la visibilidad de sus distintas organizaciones — algo que, por otra parte, se logró-, no hay que olvidar que la cumbre de cancilleres tenía lugar en México, un país que, desde el estallido de la Guerra Civil, había apoyado sin tibiezas la causa republicana desde la tribuna de la Sociedad de las Naciones, por medio de la venta de pertrechos de guerra e, incluso, con la recepción durante el conflicto de los niños de Morelia y, ya después, de los grandes contingentes de refugiados (véase, entre otros, Matesanz, 1980; Sola Ayape, 2008; Sánchez y Herrera, 2011).

A decir verdad, pocos países como México conocían tan bien la problemática española, y pocos como él seguían manteniendo su doble e irrenunciable compromiso: primero, con el reconocimiento de la legitimidad del republicanismo español en el exilio y, segundo, con el desconocimiento del régimen político impuesto por Franco en España tras el triunfo del bando nacional (Sola Ayape, 2016b). El nuevo presidente de la República, el católico Manuel Ávila Camacho, había asumido la herencia cardenista, sustentada en la complicidad con el republicanismo español, inaugurando desde entonces lo que sería una política de Estado, ajena a coyunturas sexenales o a personalismos de sus presidentes (Mateos, 2004, pp. 405-443). A la postre, desde 1936 y durante el tiempo en que duró el franquismo, el régimen presidencialista mexicano y el exilio republicano español gestaron una mancuerna indisociable, hasta el grado de que el exilio español formó parte del imaginario político de aquel régimen posrevolucionario (Sola, 2016a, 535 pp.).

Por eso, después de la celebración de varias cumbres interamericanas, al compás de la nueva diplomacia del "buen vecino" inaugurada en 1933, México hacía en aquella ocasión las veces de anfitrión, eligiendo además una sede que por derecho propio se había convertido en la capital simbólica del exilio republicano español. En efecto, en la ciudad de México, desde donde se gobernó durante tres siglos los destinos de la Nueva España, se encontraba la sede de la Diputación Permanente de las Cortes Republicanas Españolas, se había fundado la JEL en noviembre de 1943, radicaban importantes asociaciones, agrupaciones y partidos políticos republicanos, se encontraban residiendo líderes de tanta significación política como el socialista Indalecio Prieto — verdadero administrador de los tesoros del Vita y, por consiguiente, de la financiación del exilio-y, entre otros tantos elementos a destacar, la capital mexicana 
había sido recientemente, primero, la sede del primer intento — en vano- de celebración de las cortes republicanas en el exilio por iniciativa de Diego Martínez Barrio (10 de enero) y, segundo, el gran mitin republicano en la Arena México para cerrar filas en torno a la figura de Juan Negrín (29 de enero). En pocas palabras, a tenor de estos apuntes, los exiliados españoles parecían jugar en casa durante la celebración de aquella cumbre panamericana (Romero, 2005, pp. 245 y 246).

Tal como se ha mostrado en estas páginas, teniendo a los cancilleres de América como sus principales destinatarios, al castillo de Chapultepec fueron remitidos diferentes comunicados del exilio español, así como otros que se hicieron públicos en la prensa diaria, tanto mexicana como internacional. Durante aquellos días, fue extraño ver las páginas de un solo periódico mexicano que no se hiciera eco de alguna noticia relacionada con la problemática de los refugiados españoles, destacando también aquellos comunicados procedentes de organizaciones mexicanas afines a la causa del exilio español.

Como denominador común, los documentos enviados desde diferentes frentes del exilio se hicieron eco de las tradicionales tesis que, desde el fin de la guerra, habían conformado el soporte argumentativo de las diferentes declaraciones oficiales del exilio, entre ellas, las que recuperamos para la ocasión:

1. La vigencia del orden institucional republicano emanado del 14 de abril de 1931.

2. La Segunda Guerra Mundial había comenzado en España el 18 de julio de 1936.

3. La España republicana fue la primera víctima del nazi-fascismo.

4. El pueblo español fue el primero en derramar su sangre por defender la libertad y la democracia en el mundo.

5. El afán del pueblo español, tanto dentro como fuera de España, por seguir luchando hasta acabar con el régimen franquista y recuperar las libertades republicanas.

6. Franco había ganado la guerra gracias al apoyo militar y logístico de Adolf Hitler y Benito Mussolini.

7. La raíz fundacional del gobierno de Franco era nazi-fascista.

8. El franquista había sido un régimen represor y carcelario desde su origen y lo seguía siendo siete años después.

9. El problema del republicanismo del exilio no era un problema únicamente español, sino mundial. 
10. El triunfo de la democracia debía conllevar la reposición del status quo reinante en Europa, sin distingo de lugares, anterior a la irrupción de los “ismos" totalitarios como el nazismo, el fascismo o el franquismo.

Y, sin embargo, conjuntamente con esta exposición de motivos, los exiliados españoles presentaron para los cancilleres otros argumentos que éstos sí, a su entender, representaban una seria amenaza para los intereses de los países del continente americano:

1. El falangismo como movimiento de raíz ideológica nazi-fascista.

2. El peligro de la extensión del falangismo en América.

3. La tesis de la Hispanidad como herramienta de legitimación y penetración del franquismo en América.

4. La reciente ejemplaridad de Guatemala que, tras salir de la dictadura, había roto de inmediato los lazos diplomáticos con la España franquista.

Finalmente, frente a esta exposición de motivos, se hacía un llamamiento, primero, para que de forma conjunta los países americanos allí representados reconocieran la legalidad y la legitimidad de la República Española, por más de que ésta se encontrara en el exilio y, segundo, una ruptura de las relaciones diplomáticas con la España franquista, como medida para imponer un cerco al régimen franquista, y antesala a la posible respuesta que en esta dirección habría de tomarse en la Conferencia de San Francisco.

Como se observa, la presente Conferencia de cancilleres sirvió para sondear el apoyo americano a su causa y conocer una vez más la composición discursiva del exilio español y también sus advertencias sobre la penetración ideológica del falangismo de raíz nazi-fascista en el continente americano, entre otras vías, a través de la Hispanidad, esa "fase nueva de sentido histórico de la raza inventada por Franco [...] con el propósito de poner estos países al servicio de las ideas con que ha logrado mediante los moros y el auxilio extranjero encadenar a España” (España. Órgano de la Junta España de Liberación, 1945, 21 de abril, p. 8).

En el fondo, a tenor de lo visto, hay que decir que en el castillo de Chapultepec se escenificaron dos de las grandes tragedias que asedió la biografía del exilio desde su inicio hasta la disolución de sus instituciones en junio de 1977: la primera, su falta de personalidad jurídica y, en consecuencia, su presencia informal, y hasta meramente testimonial, en este tipo de cumbres internacionales, que siempre le 
obligó a hacer su particular juego diplomático entre bambalinas y, a la postre, a quedar entrampado en el desconcertante escenario de la rumorología y, la segun$\mathrm{da}$, aunque ligada a la anterior, la imperiosa necesidad de depender de terceros países que, por lo general, concibieron la problemática española según intereses particulares soberanos y siempre a expensas de las cambiantes circunstancias de la coyuntura internacional, muy especialmente durante aquellos meses de posguerra y ya durante la tensa y bipolar Guerra Fría. Así, el clamor del exilio español en el marco Chapultepec también puede verse como una simbólica sanción moral hacia aquellos países - no sólo americanos - que, presumiendo de democracia y de antifascismo, no quisieron - ni pudieron — verse en el espejo del exilio español..$^{35}$

De la Conferencia de Chapultepec, el exilio español salió enredado en su propio laberinto. La mayoría de los refugiados — gente anónima y desperdigada por la vasta geografía de la diáspora-, padeció la decepción que dejó una incomprensión interna y externa. ${ }^{36}$ Tras Chapultepec, la suerte del exilio estaba echada, a pesar del provisional estado de euforia y esperanza que se alcanzaría en la inmediata Conferencia de San Francisco, donde se pudo ver, una vez más, a un exilio errante que llevaría la defensa de su causa a esta ciudad californiana, siguiendo la senda de la celebración de estas grandes conferencias internacionales, aunque supeditado al compás de las decisiones de unos y otros.

Cerramos el presente artículo, recuperando para este propósito dos testimonios de alto valor simbólico, extraídos de aquella prensa republicana del exilio. Se trata de fragmentos seleccionados de dos editoriales de prensa, próximos en fechas, ambos publicados cuando los cancilleres de América seguían discutiendo entre los muros del castillo de Chapultepec en torno a las vicisitudes sobre la guerra y la paz, y cuando todavía resonaba el discurso inaugural del presidente Ávila Camacho y, en especial, aquellas palabras cuando afirmó que tenía la convicción de que, en la

\footnotetext{
35 Lo cierto es que ni en las conferencias de Teherán (noviembre de 1943), de Yalta (febrero de 1945), de Potsdam (agosto de 1945), ni en la Conferencia de San Francisco, de donde salió la Organización de las Naciones Unidas, se hizo referencia alguna al gobierno, instituciones u organizaciones republicanas españolas que, sobre el papel, representaban la legalidad democrática de un país, primero, no admitido en la ONU y, segundo, marginado internacionalmente por la complicidad de su régimen con el nazi-fascismo (Moradiellos, 1999, p. 54).

36 La prensa franquista hizo el siguiente balance de la cumbre de cancilleres de Chapultepec: "Ese impertinente aldabonazo guatemalteco a la Conferencia de Méjico, tratando de exhibir su conducta con España como ejemplo político, fue totalmente desoído, y aunque los intrigantes que actúan detrás de la cortina política cifran ahora sus esperanzas en la Conferencia de San Francisco - allí estará Rusia, dicen, confiados-, lo cierto es que Madrid ha tenido dos éxitos diplomáticos con el fracaso de las llamadas Cortes republicanas de Méjico y el carpetazo dado a la propuesta de ruptura de relaciones que algunos intentaban hacer prosperar. Y con esto el horizonte diplomático español aparece despejado" ( $A B C, 1945,14$ de marzo, p.9).
} 
organización de la nueva paz, "la palabra América podría ser garantía espléndida de equilibrio".

En el primero de ellos, publicado en República Española - periódico del exilio de reciente aparición y dirigido por el periodista cordobés Fernando Vázquez Ocaña-, se hacía la siguiente advertencia, también para los cancilleres americanos. Haciendo una clara alusión a la exclusión del problema español de la Conferencia Interamericana, esgrimiéndose el argumento de que no se trataba de un asunto exclusivamente americano, he aquí lo que se dijo: "Si persisten y triunfan las curiosas distinciones de la hora presente, la República Española no sentirá la menor necesidad de sentarse a la Mesa de la Paz, porque, si los principios por los que han muerto y continúan muriendo millones y millones de seres humanos han de ser burlados, mejor es que sea Francisco Franco el que participe en la burla" (República Española, 1945, 28 de febrero, p. 10).

En cuanto al segundo, divulgado en España, el periódico de la JEL, secundando el mismo tono de ironía, incredulidad y hasta de desencanto, advertía que "el drama de España" seguía sin tener "público" y, en consecuencia, ante la pasividad e indiferencia teatralizada en la cumbre americana, seguirían en la España franquista "despertando al alba las dianas de los fusilamientos y dibujando su silueta las horcas en las losas de los presidios". Y, entre tanto, "los cancilleres, que se hicieron el sordo cuando se les habló de España, continúan en su asamblea, graves, estirados, citando a la Justicia, a la Libertad, a la Fraternidad. Todas las bellas y casi siempre inútiles palabras con que la mayoría de los hombres adormecen sus inquietudes de conciencia". ${ }^{37}$

\section{BibLIOGRAFÍA}

Albornoz, A. de (1944). Izquierda Republicana en la Junta Española de Liberación. Distrito Federal, México: Ateneo Salmerón.

Alonso García, M. R. (2004). Historia, diplomacia y propaganda de las instituciones de la República Española en el Exilio (1945-1962). Madrid, España: Fundación Universitaria Española.

Alted, A. (2005). La voz de los vencidos: El exilio republicano de 1939. Madrid, España: Aguilar.

\footnotetext{
37 El título del editorial no podía ser más expresivo: "Mientras los cancilleres hablan" (España. Órgano de la Junta Española de Liberación, 1945, 3 de marzo, p. 1).
} 
Angosto, P. L. (2009). La República en México. Con plomo en las alas. Sevilla, España: Espuela de Plata.

Azcárate, P. de (2010). En defensa de la República: Con Negrín en el exilio. Barcelona, España: Crítica.

Cabeza Sánchez Albornoz, S. ( 1997). Historia politica de la Segunda República en el Exilio. Madrid, España: Fundación Universitaria Española.

Cabezas, O. (2005). Indalecio Prieto, socialista y español. Madrid, España: Algaba.

Colom González, F. (2006). El hispanismo reaccionario. Catolicismo y nacionalismo en la tradición antiliberal española. En F. Colom y A. Rivero (eds.). El altar y el trono. Ensayos sobre el catolicismo politico iberoamericano (pp. 43-82). Barcelona, España: Anthropos.

Delgado Gómez Escalonilla, L. (1988). Diplomacia franquista y politica cultural hacia Iberoamérica, 1939-1953. Madrid, España: CSIC, Centro de Estudios Históricos.

Espadas Burgos, M. (1987). Franquismo y politica exterior. Madrid, España: RIALP. Hernando Noguera, L. C. (2013). Complejas alianzas. La experiencia de la Junta Española de Liberación. En M. C. Serra Puche, F. Mejía Flores y C. Sola Ayape (eds.). 1945, entre la euforia y la esperanza: El México posrevolucionario y el exilio republicano español (pp. 49-79). Distrito Federal, México: Fondo de Cultura Económica, Cátedra del Exilio, CIALC.

Herrera GonZÁLEZ, P. (2013). La cuestión franquista y la posición obrera latinoamericana: Las acciones de Vicente Lombardo Toledano. En M. C. Serra Puche, F. Mejía Flores y C. Sola Ayape (eds.). 1945, entre la euforia y la esperanza: El México posrevolucionario y el exilio republicano español (pp. 215-231). Distrito Federal, México: Fondo de Cultura Económica, Cátedra del Exilio, CIALC.

Lombardo Toledano, V. (1945a). Balance de la Conferencia Interamericana de Chapultepec. Distrito Federal, México: CTAL.

Lombardo Toledano, V. (1945, 11 de marzo). Balance de la CTAL acerca de la Conferencia Interamericana. El Popular.

López SÁnchez, J. M. (2013). Los refugios de la derrota: El exilio cientifico e intelectual republicano de 1939. Madrid, España: Consejo Superior de Investigaciones Científicas, Los Libros de la Catarata.

Mateos, A. (2004). Tiempos de guerra, tiempos de desesperanza. La política de Ávila Camacho hacia España y el exilio republicano en México, 1940-1943. Historia Mexicana, 54(2): 405-443. 
Matesanz, J. A. (1978). México y la República Española. Antología de documentos, 1931-1977. Distrito Federal, México: Centro Republicano Español de México.

Matesanz, J. A. (1980). De Cárdenas a López Portillo. México ante la República española 1936-1977. Estudios de Historia Moderna y Contemporánea de México. Vol. 8, editado por A. Matute, con la colaboración de R. Sánchez Flores (pp. 179-231). Distrito Federal, México: Instituto de Investigaciones Históricas de la Universidad Nacional Autónoma de México.

Moradiellos, E. (1999). Potsdam, 1945. El franquismo en entredicho. Claves de Razón Práctica, 92(abril): 54-60.

Moradiellos, E. (2001). El reñidero de Europa: Las dimensiones internacionales de la Guerra Civil Española. Barcelona, España: Península.

Moradiellos, E. (2006). Negrín. Barcelona, España: Península.

PARdo SAnz, R. (1995). Con Franco hacia el Imperio: La politica exterior española en América Latina, 1939-1945. Madrid, España: Universidad Nacional de Educación a Distancia.

Portero, F. (1989). Franco aislado. La cuestión española (1945-1950). Madrid, España: Aguilar.

Romero SAmper, M. (2005). La oposición durante el franquismo/3. El exilio republicano. Madrid, España: Ediciones Encuentro.

S. A. (1946).Autógrafo de S. E. el Señor Presidente de la República y discursospronunciados para conmemorar el XV aniversario de la proclamación de la República Española. París, Francia: Imprimiere S. P. I.

SÁnchez Andrés, A., y Herrera León, F. (2011). "Contra todo y contra todos". La diplomacia mexicana y la cuestión española en la Sociedad de Naciones, 1936-1939. Santa Cruz de Tenerife, España: Idea.

SÁnChez Cervelló, J. (2011). La Segunda República en el exilio (1939-1977). Barcelona, España: Planeta.

Serra Puche, M. C.; Mejía Flores, F., y Sola Ayape, C. (eds.) (2013). 1945, entrela euforia y la esperanza: El México posrevolucionario y el exilio republicano español. Distrito Federal, México: Fondo de Cultura Económica, Cátedra del Exilio, CIALC.

Serra Puche, M. C.; Mejía Flores, F., y Sola Ayape, C. (coords.) (2015). Politica y sociedad en el exilio republicano español. Ciudad de México, México: Centro de Investigaciones sobre América Latina y el Caribe de la Universidad Nacional Autónoma de México, Cátedra del Exilio.

Sola Ayape, C. (2008). Entre fascistas y cuervos rojos: España y México (1934-1975).

Distrito Federal, México: Porrúa, Tecnológico de Monterrey. 
Sola Ayape, C. (2009). A ganar la Guerra Civil española: México contra Franco en la Conferencia de San Francisco de 1945. Casa del Tiempo, II(24): 153-159.

Sola Ayape, C. (2013). De la esperanza al desencanto: El exilio español en el México de Manuel Ávila Camacho (1940-1946). Historia del Presente, 22(2a época): 57-74.

Sola Ayape, C. (2016a). Los diplomáticos mexicanos y la Segunda República Española (1931-1975). Madrid, España: Fondo de Cultura Económica.

Sola Ayape, C. (2016b). De Cárdenas a Echeverría: Los 12 puntos de la política exterior de México hacia la España de Franco (1936-1975). Foro Internacional, 56(224): 321-377.

Sola Ayape, C. (2015a). Y América dijo no. La Conferencia de Cancilleres de Chapultepec de 1945 ante el problema del exilio español. En M. C. Serra Puche, F. Mejía Flores y C. Sola Ayape (coords.) (2015). Política y sociedad en el exilio republicano español (pp. 75-88). Ciudad de México, México: Centro de Investigaciones sobre América Latina y el Caribe de la Universidad Nacional Autónoma de México, Cátedra del Exilio.

Sola Ayape, C. (2015b). América Latina ante la Spanish Question: El régimen franquista como eje de la discordia en la ONU (1945-1950). Latinoamérica. Revista de Estudios Latinoamericanos, 61(octubre): 65-95.

Velázeuez Flores, R. (2007). Lapolitica exterior de México durante la Segunda Guerra Mundial. Distrito Federal, México: Plaza y Valdés Editores, Universidad del Mar. Velázquez Hernández, A. (2014). Empresas y finanzas del exilio. Los organismos de ayuda a los republicanos españoles en México (1939-1949). Distrito Federal, México: El Colegio de México.

Yuste de Paz, M. A. (2005). La II República Española en el Exilio en los inicios de la Guerra Fría (1945-1951). Madrid, España: Fundación Universitaria Española. 


\section{ANEXO 1}

Organizaciones españolas del exilio, firmantes de un comunicado dirigido a la Conferencia de Cancilleres de Chapultepec (26 de febrero de 1945)

1. Círculo Cultural “Jaime Vera” (César Rodríguez, Félix Carreras).

2. Comité Local de la Unión General de Trabajadores de España (Eduardo Mazón, José Satue).

3. Delegación en México del Partido Comunista de España (Felipe Arconada, Ricardo Castellote).

4. Centro de Unidad Republicana (Arturo Cortés).

5. Comité Regional de la Confederación Nacional del Trabajo de Asturias, León y Palencia (Antonio González Nieto).

6. Delegación en México del Partido Socialista Unificado de Cataluña (Luis G. Lago, Luis Salvadores).

7. Federación de Agrupaciones Regionalistas Socialistas (José Sosa, Vicente Sarmiento).

8. Alianza Nazonal Gallega (Salvador Etchevarría)

9. Ateneo Pi y Margall (Antonio Orallo)

10. Centro Andaluz (Gabriel Morón)

11. Partido Galleguista (Juan García)

12. Fogar Gallego (Juan Moré)

13. Ateneo Ramón y Cajal (Manuel Márquez)

14. Agrupación de Militares Republicanos (coronel Patricio Azcárate)

15. Comisión Central de Ayunta a la Junta Suprema (Pedro Carrasco)

16. El Casal Catalá (José Puig, José Muni)

17. Agrupación Española de Escritores y Periodistas (Arturo Mori, Emilio Criado Romero).

18. Juventudes Socialistas Unificadas de España (Federico Melchor)

19. La JSU de Cataluña (Gregorio López Raymundo)

20. Comité Peninsular de las Juventudes Libertarias (Serafín Aliaga)

21. Unión de Jóvenes Patriotas (Miguel Prieto)

22. Comité Nacional de Mujeres Antifascistas (Trinidad Arroyo)

23. Comité de Mujeres "Mariana Pineda" (Magdalena Pinzano)

24. Federación de Trabajadores de la Enseñanza (César G. Lobardia)

25. Sindicato Nacional Ferroviario (Saturnino Jimeno) 
26. Sindicato Nacional de Marinos (Manuel Vidal Révora)

27. Federación de Funcionarios Públicos de España (Santiago Romanillos)

28. Federación Obrera de Hostelería de España (Hilario Caloto)

29. Sindicato Nacional de Petroleros (Daniel Anguiano)

30. Sindicato Nacional de Telégrafos (J. González Olivares)

31. Federación Obrera Telefónica Española (Manuel Sobrino)

32. Unión de Radiotelegrafistas Españoles (Joaquín F. Bustos)

33. Sindicato Nacional de Carteros Urbanos (Carlos Riedo)

34. Federación Nacional de Auxiliares de Farmacia (J. Cuadrado)

35. Secretario de Cataluña de la Unión General de Trabajadores (J. Molinero)

36. Federación Española de Espectáculos Públicos (Aguilar)

37. Sindicato Nacional del Instituto de Previsión (Ricardo Rodríguez Bedia) 